\title{
The Contribution of the Precautionary Principle to Marine Environmental Protection
}

\author{
From Making Waves to Smooth Sailing?
}

Warwick Gullett

\section{Introduction}

In 2002, Professor David VanderZwaag wrote an article examining the precautionary principle and marine environmental protection, characteristically entitling it with poetic ocean imagery and alliteration. ${ }^{1}$ The article was written just on a decade after the precautionary principle's heyday of international acclaim and alarmist criticism in the early to mid-199os and at a time appropriate for reflection on whether the principle had advanced marine environmental management, including analysing implementation challenges. VanderZwaag argued the precautionary principle had created various 'slippery shores' including terminological confusion and philosophical tensions and faced 'rough seas' in trying adequately to respond to problems such as overfishing, but was promising to synergize with other principles of sustainable development in 'rising normative tides'. He reflected on a key reason why the principle has been so controversial as a regulatory tool to address environmental risks and uncertainties. In his inimitable prose: the 'conceptual shores of precaution are ... slickened by competing philosophical and cultural values and socioeconomic interests, where persons often disagree over how precautionary society should be.' ${ }^{2}$ He considered the precautionary principle was still in its infancy yet its enduring legacy was clear, concluding positively that it

is not an endpoint but helps chart a course. The principle plots new directions for governance. No longer should regulators or the public have

1 D VanderZwaag, 'The Precautionary Principle and Marine Environmental Protection: Slippery Shores, Rough Seas, and Rising Normative Tides' (2002) 33 Ocean Development \& International Law 165-188; see also, for example, D VanderZwaag, S Fuller, and R Myers, 'Canada and the Precautionary Principle/Approach in Ocean and Coastal Management: Wading and Wandering in Tricky Currents' (2002-2003) 34 Ottawa Law Review 117-158.

2 VanderZwaag (2002), ibid 168. 
to demonstrate environmental harm before precautionary measures are required. No longer should technical experts and other professionals be the sole voices in deciding safety and acceptability. No longer should corporate and human interests automatically trump biodiversity values. ${ }^{3}$

By the end of the twentieth century the precautionary approach appeared frequently in national environmental legal systems ${ }^{4}$ and had 'infiltrated virtually every international environmental and natural resource treaty regime. 5 From the heady days of the 1990s when the principle was fiercely debated for making waves by presenting, according to some commentators, a fundamental challenge to the existing legal order ${ }^{6}$ and a wholesale rejection of scientific methodology as a basis for decision-making, ${ }^{7}$ the precautionary principle literature is now a sea of much calmer waters, albeit ripples persist. ${ }^{8}$ Many key debates about the precautionary principle have been thoroughly canvassed, such as concerning its reversal of the burden of proof, ${ }^{9}$ its relationship with

$3 \quad$ Ibid 176.

4 Various tabulations of legislative inclusions of the precautionary principle have been conducted. See, for example, R Unger, 'Brandishing the Precautionary Principle through the Alien Torts Claims Act' (2001) 9 New York University Environmental Law Journal 638692, 66o-663.

5 D Freestone, 'International Fisheries Law since Rio: The Continued Rise of the Precautionary Principle' in A Boyle and D Freestone (eds), International Law and Sustainable Development (Oxford, 1999) 135-164, 135.

6 For example, Weintraub argued the principle departs from traditional tortious notions of liability in which no harm is presumed until evidence is presented of damage and causation: BA Weintraub, 'Science, International Environmental Regulation, and the Precautionary Principle: Setting Standards and Defining Terms' (1992) 1 New York University Environmental Law Journal 173-223, 178. See also Frank Cross, 'Paradoxical Perils of the Precautionary Principle' (1996) 53 Washington and Lee Law Review 851-925.

7 For example, Gray argued the principle 'has nothing to do with science' because it enables judgments to be made without sufficient objectivity and statistical validity: JS Gray, 'Statistics and the Precautionary Principle' (1990) 21 Marine Pollution Bulletin 174-176, 174. Similarly, Bewers stated that the principle 'has no particular bearing or relevance to scientific methods of assessment': JM Bewers, 'The Declining Influence of Science on Marine Environmental Policy' (1995) 10 Chemistry and Ecology 9-23, 14. See also, A Milne, 'The Perils of Green Pessimism' New Scientist (12 June 1993) 34.

8 This is possibly especially the case in the fields of risk regulation and international investment law. See, for example, CR Sunstein, Laws of Fear: Beyond the Precautionary Principle (Cambridge University Press, 2005) and L Kogan and L Bergkamp, 'Trade, the Precautionary Principle, and Post-modern Regulatory Process: Regulatory Convergence in the Transatlantic Trade and Investment Partnership' (2013) 4 European Journal of Risk Regulation 493-507, 501 who consider the precautionary principle is 'postmodern revenge' on science.

9 In the context of approval processes for new developments or activities, the precautionary principle is generally understood as shifting the burden of proof from 
science ${ }^{10}$ and decision-making rationality, ${ }^{11}$ and the semantic distinction between precautionary 'principle' and 'approach.12 One of the earliest debates about the principle - whether it had crystallized into a norm of customary international law - has been 'virtually exhausted as a research agenda..13 Some far less fiery debates have emerged. They are located closer to the margins of how the principle operates rather than contesting its fundamental underpinnings. One of the most sustained recent debates concerns the question of whether it is Europe or the United States (US) which is the most advanced in precaution. ${ }^{14}$ The voluminous precautionary principle literature of the 199os,

environmentalists (that of proving that a proposed development would cause significant harm) to developers (to prove that it would not cause such harm). See, for example, W Gullett, 'Environmental Protection and the Precautionary Principle: A Response to Scientific Uncertainty in Environmental Management' (1997) 14 Environmental and Planning Law Journal 52-69, 59-6o; J Jones and S Bronitt, 'The Burden and Standard of Proof in Environmental Regulation: The Precautionary Principle in an Australian Administrative Context' in E Fisher, J Jones and R von Schomberg (eds), Implementing the Precautionary Principle: Perspectives and Prospects (Edward Elgar, 2006) 137.

10 See, for example, KR Foster, P Vecchia and MH Repacholi, 'Science and the Precautionary Principle' (2000) 288 Science 979-981; J Tickner and D Kriebel, 'The Role of Science and Precaution in Environmental and Public Health Policy' in Fisher, Jones and von Schomberg (eds), above (n 9), 42; B Wynne, 'Uncertainty and Environmental Learning: Reconceiving Science in the Preventative Paradigm' (1992) 2 Global Environmental Change 111-127.

11 See, for example, J Peel, 'When (Scientific) Rationality Rules: (Mis)application of the Precautionary Principle in Australian Mobile Phone Tower Cases' (2007) 19 Journal of Environmental Law 103-120; E Fisher, Risk Regulation and Administrative Constitutionalism (Hart, 2007).

12 See, for example, E Hey, 'The Precautionary Concept in Environmental Policy and Law: Institutionalizing Caution' (1992) 4 Georgetown International Environmental Law Review 303-318, 304; S Marr, The Precautionary Principle in the Law of the Sea: Modern Decision Making in International Law (Martinus Nijhoff, 2003) 17-21.

13 J Ellis, 'Overexploitation of a Valuable Resource? New Literature on the Precautionary Principle' (2006) 17 European Journal of International Law 445-462, 449. See, for example, A Trouwborst, Evolution and Status of the Precautionary Principle in International Law (Kluwer, 2002). Indeed, development of international environmental law jurisprudence confirms that the precautionary principle extends the preventive requirements of the 'due diligence' obligation with respect to causation of transboundary environmental harm. See Gullett (1997), above (n 9), 57; D Anton, 'The Principle of Residual Liability in the Seabed Disputes Chamber of the International Tribunal for the Law of the Sea: The Advisory Opinion on Responsibility and Liability for International Seabed Mining (ITLOS case no. 17)' (2011) 7(2) McGill International Journal of Sustainability Law and Policy 241-257, 244; L Chen, 'Realizing the Precautionary Principle in Due Diligence' (2016) 25 Dalhousie Journal of Legal Studies 1.

14 See, for example, JB Wiener, MD Rogers, JK Hammit and PH Sands (eds), The Reality of Precaution: Comparing Risk Regulation in the United States and Europe (Routledge, 2011). Indeed, differences in approach to risk regulation in Europe and the United States across 
which had developed 'at an alarming rate', 15 has waned. Articles now tend to be devoted to more discrete issues within particular sectors, such as precautionary regulatory decisions possibly resulting in compensable indirect expropriation of foreign investments. ${ }^{16}$ Criticism of the principle's appositeness to environmental matters is virtually absent. In the 'state of origin' of the precautionary approach - marine environmental protection - it remains entrenched in the international legal and policy framework and is a core component, in one form or another, in domestic law in States with advanced environmental regulatory structures. Yet is the seemingly smooth sailing now enjoyed by the precautionary principle due to belated acceptance that the earlier vociferous fearmongering and alarmist rhetoric of its critics was inherently unsound, or is the principle simply now perceived as less-threatening because of a lack of implementation zeal by regulators, to the disappointment of its equally impassioned advocates?

Has the precautionary principle lived up to its immense expectations? How is the precautionary principle to be evaluated now, a quarter of a century after it leapt onto the international stage as an apparent paradigm shift in environmental management and new frontier of legal principle when it was included in the 1992 United Nations Rio Declaration on Environment and Development? Principle 15 of the Rio Declaration remains the most significant explicit international recognition of the principle. It commits its more than 170 signatory States to widely apply the precautionary approach, 'according to their capabilities', in order to protect the environment. The precautionary commitment stipulated remains the most widely adopted and influential formulation of the precautionary approach:

Where there are threats of serious or irreversible damage, lack of full scientific certainty shall not be used as a reason for postponing costeffective measures to prevent environmental degradation. ${ }^{17}$

many fields have presented difficulties in negotiations for the long-awaited Transatlantic Trade and Investment Partnership. See, for example, H Davies, 'Investor-State Dispute Settlement and the Future of the Precautionary Principle' (2016) 5 British Journal of American Legal Studies 449-538, 470.

15 Ellis, above (n 13), 446.

16 See, for example, Davies, above (n 14).

17 UN Doc A/CONF.151/26 (Vol 1) (12 August 1992), Annex 1, Principle 15. 
Notwithstanding this formulation's tortuous triple-negative phraseology, ${ }^{18}$ this seemingly innocuous and common sense principle - that an absence of full scientific knowledge in situations of threatened serious environmental damage should not be used as an excuse to avoid taking affordable prevention measures - has 'incited an astonishing amount of interest' ${ }^{19}$ and has 'engendered endless controversy'20 despite its widespread political acceptance. Yet the precautionary principle is a constructed legal and policy frontier. It is not designed to address new problems because there has always been awareness of limits in knowledge. However, it focuses explicitly on identifying ways to respond effectively to wide-ranging uncertainty, and hence to ensure examination of the limits of knowledge about environmental process and the effects of human activities. Exhaustive debates are generated because the principle can be immensely challenging and confronting for public resource decisionmaking: it seeks to mould changes to the way in which intractable problems are addressed, in a manner that is inevitably fundamentally mutable in application.

Writing in 1999, Professor David Freestone argued that the issue for the next century is the extent to which the rhetoric of the principle can be operationalized - the extent to which precautionary methodologies can be developed to give effect to what is otherwise an abstract concept. ${ }^{21}$ VanderZwaag concluded his 2002 article by noting that 'a major challenge will be to track the progress of the precautionary principle' given its 'broad policy implications to so many resource sectors, from aquaculture and fisheries to pollution control and to so many levels of governance (local, national, regional, and international). ${ }^{22}$ Indeed, the precautionary principle does not simply have strong currents in marine and fisheries law and other areas of environmental management. It has branched out to many other fields of human endeavour; most notably chemical regulation, food safety and broader fields of public health, biosafety, climate change strategy and international investment law. The task of tracking its progress is also bedevilled by the literature - as analysed by Ellis more than a decade ago - being 'crowded'23 and increasingly

18 CD Stone, 'Is There a Precautionary Principle?' (2001) $3^{1}$ Environmental Law Reporter 10790-10799, 1079 o.

19 Ellis, above (n 13), 445-446.

$20 \quad$ Foster, Vecchia and Repacholi, above (n 10), 979.

21 D Freestone, 'International Fisheries Law since Rio: The Continued Rise of the Precautionary Principle' in Boyle and Freestone (eds), above (n 5), 135-164, 135.

22 VanderZwaag 2002, above (n 1), 176.

23 Ellis, above (n 13), 445-446. 
sector-specific, giving rise to a 'sprawling interpretative commentary that casts the principle in many different disciplinary lights'. ${ }^{24}$

This chapter considers the success of the precautionary principle in improving marine environmental protection decision-making, including how limitations in environmental knowledge influence legal and policy administrative structures. The chapter provides a brief historical overview of the precautionary principle and its major international milestones in international instruments and examines its development in its foundational field of marine environmental protection. The genetic heritage of the principle is traced further back in history than its initial formal explicit articulation in environmental policy to help conceptualize its frontier traits that inform how the principle is constructed and implemented. The use of precaution in marine pollution control and international fisheries management is reviewed together with illustrative implementation challenges of precaution in domestic fisheries legal regimes. Consideration is given to whether the precautionary principle has moved beyond a legal obligation to a situation where it influences behaviour and helps to resolve problems. The chapter concludes with a response to Freestone's prescient 1999 observation:

Innovative and precautionary environmental regimes which are not implemented effectively may not simply be worthless: they may be worse than worthless if they give the impression that all is well when the opposite is in fact true. ${ }^{25}$

Understanding the Precautionary Principle: Origins, Development and Meaning

\subsection{Origins}

Freestone characterized the precautionary principle as having been 'born before it was conceived'. ${ }^{26}$ In 1991 he called the principle 'the most important new policy approach in international environmental co-operation' and

24 E Fisher, 'Precaution, Precaution Everywhere: Developing a 'Common Understanding' of the Precautionary Principle in the European Community' (2002) 9 Maastricht Journal of European and Comparative Law 7-28, 13 .

25 D Freestone, 'The Challenge of Implementation: Some Concluding Notes' in Boyle and Freestone (eds), above (n 5), 359-364, 36o.

26 D Freestone, 'The Road From Rio: International Environmental Law After the Earth Summit' (1994) 6 Journal of Environmental Law 193-218, 210. 
observed that it had recently emerged on the international agenda and been explicitly accepted in a variety of international forums with 'staggering' speed, ${ }^{27}$ yet commentators had been unable to conceive its precise meaning. It had been accepted in international environmental forums without detailed articulation of specific obligations of actions or processes. The 'general thrust' of the principle could be outlined, and a number of different themes identified, ${ }^{28}$ yet step-by-step practitioner-oriented legally-supported guidance would remain elusive in most fields for years to come.

The principle's emergence in international negotiations occurred during the early-1980s in the lead-up to the North Sea Conferences ${ }^{29}$ as a result of its advocacy by the Federal Republic of Germany, drawing on its status as a foundational domestic legal principle of precautionary action (vorsorgeprinzip) and an entrenched component of national environmental policy. ${ }^{30}$ The first explicit endorsement of the principle in an international agreement came in November 1987 in the London Declaration of the Second International Conference on the Protection of the North Sea. The participants accepted that

in order to protect the North Sea from possibly damaging effects of the most dangerous substances, a precautionary approach is necessary which may require action to control inputs of such substances even before a causal link has been established by absolutely clear scientific evidence. ${ }^{31}$

The parties put the principle into effect by agreeing to reduce polluting emissions of substances that

are persistent, toxic and liable to bioaccumulate at source by the use of the best available technology and other appropriate measures. This

27 D Freestone, 'The Precautionary Principle' in R Churchill and D Freestone (eds), International Law and Global Climate Change (Graham \& Trotman, 1991) 21-39, 36.

28 Freestone (1994), above (n 26).

29 The North Sea Conferences were a series of conferences which commenced in Bremen in 1984 in which North Sea States worked collectively to address the problem of pollution of the North Sea as a result of land-based pollutants and ocean dumping. As a milestone development, the precautionary principle was adopted at the second conference in London in 1987. Six conferences have been held with the last in Gothenburg in 2006. See D Freestone and T Ijlstra, 'The North Sea: Perspective on Regional Environmental Cooperation-Introduction' (1990) 5 International Journal of Estuarine and Coastal Law xix.

30 L Gündling, 'The Status in International Law of the Principle of Precautionary Action' (1990) 5 International Journal of Estuarine and Coastal Law 23-30, 23-24.

31 Reproduced in D Freestone and T Ijlstra (eds), The North Sea: Basic Legal Documents on Regional Environmental Co-operation (Graham \& Trotman/Martinus Nijhoff, 1991) 40-6o. 
applies especially when there is reason to assume that certain damage or harmful effects on the living resources of the sea are likely to be caused by such substances, even where there is no scientific evidence to prove a causal link between emissions and effects ('the principle of precautionary action'). ${ }^{32}$

The principle has been advanced most successfully at the international level in relation to marine pollution ${ }^{33}$ but has also been applied to many other areas including fisheries management, ${ }^{34}$ hazardous wastes, ${ }^{35}$ climate change, ${ }^{36}$ ozone depletion, ${ }^{37}$ biodiversity, ${ }^{38}$ and general environmental management at the national and international level. ${ }^{39}$

32 Freestone (1991), above (n 27), 23-24.

33 Examples include the Final Document of the Nordic Council's International Conference on Pollution of the Seas (1989), reprinted in The Nordic Council, Nordic Council's International Conference on Pollution of the Seas (Norstedts Tryckeri AB, 1990) 94; 1992 ospaR Convention, discussed below (n 91) and accompanying text; 1992 Convention on the Protection and Use of Transboundary Watercourses and International Lakes, in force 6 October 1996, 1936 UnTs 269; 1992 Convention on the Protection of the Marine Environment of the Baltic Sea Area (with annexes and appendices), entry into force 17 January 2000, 2099 UNTS 195; and 1996 Protocol to the 1972 Convention on the Prevention of Marine Pollution by Dumping of Wastes and other Matter, entry into force 24 March 2006, [2006] ATs 11.

34 For example, Draft Convention on the Conservation and Management of Straddling Fish Stocks on the High Seas and Highly Migratory Fish Stocks on the High Seas, UN Doc A/Conf.164/L.11/Rev.1 (28 July 1993), Arts 4 and 5 and 1995 Agreement for the Implementation of the Provisions of the United States Convention on the Law of the Sea of 10 December 1982 Relating to the Conservation and Management of Straddling Fish Stocks and Highly Migratory Fish Stocks (UN Fish Stocks Agreement), 2167 UNTS 3. The precautionary aspects of the Agreement are discussed in detail by D Freestone and Z Makuch, 'The New International Environmental Law of Fisheries: The 1995 United Nations Straddling Stocks Agreement' (1996) 7 Yearbook of International Environmental Law $3^{-51 .}$

351989 Basel Convention on the Control of Transboundary Movements of Hazardous Wastes and Their Disposal, 1673 UnTs 57, Art 4(2)(e) and (g); 1991 Bamako Convention on the Ban of the Import into Africa and the Control of Transboundary Movement and Management of Hazardous Wastes Within Africa, 2101 UNTS 177, Art 4(3)(f); Agenda 21, UN Doc A/CONF.151/26/Rev.1 (Vo1 I) (12 August 1992), chapter 22, para 22.5(C).

$36 \quad 1992$ United Nations Framework Convention on Climate Change, 1771 UnTS 107, Art 3(3).

371987 Montreal Protocol to the Vienna Convention for the Protection of the Ozone Layer, 1522 UNTS 3, preamble.

381992 Convention on Biological Diversity, 176o UnTS 79, preamble.

391990 Bergen Declaration on Sustainable Development, Art 7; 199o Bangkok Declaration on Environmentally Sound and Sustainable Development in Asia and the Pacific, para 19. 
The German and Swedish origins of the principle are well known ${ }^{40}$ and its formal acceptance in 1992 as a constitutive principle of European environmental policy ${ }^{41}$ led to the predominantly negative US perception that it is 'Europe's precautionary principle',42 Although Europe has been at the forefront of legislative and policy adoption of the principle, broader analysis of what is precautionary administrative decision-making is needed to appreciate the origins of precaution as a basis for environmental management. If it is precautionary thinking that is sought, rather than formal adoption of the expressly identified principle in laws or other rules, it is apparent that the precautionary principle's underpinning philosophy is prevalent elsewhere and is of more ancient origin. ${ }^{43}$ For example, in 1991 Bodansky argued that the precautionary principle had formed the basis of US domestic environmental legislation for many years. He provided the 1972 Federal Water Pollution Control Act Amendments as an example because the legislative provisions presumed discharges of pollution are harmful to water quality and required their reduction. ${ }^{44}$ An even earlier example of US precautionary legislation that could be added to Bodansky's list is the 1969 National Environmental Policy Act (NEPA). ${ }^{45}$ This landmark Act was the world's first legislative environmental impact assessment (EIA)

40 See, for example, K von Moltke, The Vorsorgeprinzip in West German Environmental Policy (Institute for European Environmental Policy, 1987); S Boehmer-Christiansen, 'The Precautionary Principle in Germany: Enabling Government' in T O'Riordan and J Cameron (eds), Interpreting the Precautionary Principle (Earthscan, 1994) 31; B Wahlström, 'The Precautionary Approach to Chemicals Management: A Swedish Perspective' in C Raffensperger and J Tickner (eds), Protecting Public Health and the Environment: Implementing the Precautionary Principle (Island Press, 1999) 51.

41 Article 13or(2) of the 1992 Maastricht Treaty on European Union provided that European Community policy on the environment 'shall aim at a high level of protection' and 'shall be based on the precautionary principle', with such environmental protection requirements to be integrated into the definition and implementation of other European Community policies: Treaty on European Union, [1992] OJ C 191. See also subsequent amendments retaining this provision: 1997 Treaty of Amsterdam, [1997] OJ C 340, Art 174(2); 2007 Treaty on the Functioning of the European Union, [2012] OJ C 326, Art 191(2). JD Graham and S Hsia, 'Europe's Precautionary Principle: Promise and Pitfalls' (2002) 5 Journal of Risk Research 371-39o; LA Kogan, 'What Goes Around Comes Around: How UNCLOS Ratification Will Herald Europe's Precautionary Principle as US Law' (2009) 7 Santa Clara Journal of International Law 23-176.

43 Gündling, above (n 30), 29; Freestone (1991), above (n 27), 33.

44 D Bodansky, 'Scientific Uncertainty and the Precautionary Principle' (1991) 33(7) Environment 4-44, 5; see also D Bodansky, 'The Precautionary Principle in US Environmental Law' in T O'Riordan and J Cameron (eds) Interpreting the precautionary principle (Earthscan, 1994) 203.

42 USC $§ \S 4321-4375$. 
procedure, often referred to as the Magna Carta of environmental law. ${ }^{46}$ EIA and the precautionary principle are complementary: they are both means of informing environmental decision-making and influencing environmental outcomes. EIAs themselves are precautionary in a minimal sense because they are predicated on addressing uncertainty about future environmental effects. ${ }^{47}$ Implicit endorsement of precautionary reasoning is also evident at the international level prior to the 1987 London Declaration. For example, the 1982 World Charter for Nature stated that activities 'likely to pose a significant risk to nature' should not proceed where 'potential adverse effects are not fully understood. ${ }^{48}$ Precautionary thinking is also evident in the 1972 Stockholm Declaration on the Human Environment, which recognized the need to safeguard natural resources, through careful planning and management, for the benefit of future generations. ${ }^{49}$

The precautionary principle's evolution in law and policy documents occurred in parallel with the upwelling of enlightened environmental thought during the 1970s. Various streams of environmental enquiry emerged, including neo-Hobbesian environmental philosophers who argued that the insatiable period of industrialization needed to be curtailed and a post-industrial 'modernity' solution to environmental degradation found. Writers such as Ophuls ${ }^{50}$ and Heilbroner ${ }^{51}$ built on Hardin's seminal 1968 'tragedy of the commons'52 thesis and adapted political philosopher Thomas Hobbes's central argument for rule by a powerful 'Leviathan' to justify stronger environmental regulation and more effective planning and administrative structures to optimize resource use. ${ }^{53}$ Writers in this environmentalist 'survivalist' school were

$46 \quad$ BS Manheim, 'NEPA's Overseas Application' (1994) 36(3) Environment 43-45, 43.

47 WGullett, 'Environmental Impact Assessment and the Precautionary Principle: Legislating Caution in Environmental Protection' (1998) 5 Australian Journal of Environmental Management $146-58,148$.

48 United Nations General Assembly, World Charter for Nature, UN Doc A/REs/37/7 (28 October 1982), Annex, Part II, 11(b).

49 Stockholm Declaration on the Human Environment, UN Doc A/CoNF.48/14/Rev.1 (1972), Principle 2.

50 W Ophuls, Ecology and the Politics of Scarcity: Prologue to a Political Theory of the Steady State (WH Freeman \& Company, 1977); W Ophuls, 'Leviathan or Oblivion?' in HE Daly (ed), Toward a Steady-State Economy (WH Freeman, 1973) 215.

51 RL Heilbroner, An Inquiry into the Human Prospect (Norton, 1974).

$5^{2}$ G Hardin, 'The Tragedy of the Commons' (1968) 162 Science 1243-1248.

53 Hobbes was one of the first modern political philosophers. He wrote his masterpiece during the upheaval of the English Civil War. His proposed Leviathan was itself a frontier concept, proposing order and security instead of fear and uncertainty. He articulated a form of State governance which he argued would be necessary to protect citizens from a situation of inevitable turmoil resulting from increasing conflict over scarce resources. 
concerned with ways to "build a capacity for foresight into collective decision making' in order to avoid environmental collapse. ${ }^{54}$ The 'environmental crisis' debate of the early-1970s was influential in incubating innovative approaches to environmental regulation, including earlier and more effective regulatory intervention when environmental harm loomed.

Ecological theorists advocated the establishment of stronger regulatory structures as the best form of management to cope with environmental exigencies. Their viewpoint held that Western liberal thought centred on the pursuit of material goods and the sanctified concept of inalienable individual rights and liberties. This had enabled an ideology of individual freedom and unrestraint to evolve which fostered the belief that humans could dominate nature. Central to this ideology, nourished by the writings of early theorists such as John Locke and Adam Smith, was confidence in progress through science and technology and hostility to the concept of limits to human endeavours. Although the neo-Hobbesian strand of environmental reasoning met with robust criticism, ${ }^{55}$ it was influential in shaping an international discourse and understanding that environmental degradation can be significant, widespread and difficult to remedy, thereby supporting innovative and advanced approaches to the regulation of human activities. The precautionary principle can be understood as emanating from, or otherwise consonant with, this broad foundational basis in environmental discourse; it did not appear suddenly as a

The solution that he proposed was for citizens to yield-up power to an immensely powerful sovereign, either a person or a body of people, that could rule strongly and fairly in the best interests of society: T Hobbes, Leviathan (Penguin Books, 1985) [first published 1651]. Indeed Hardin's greatest intellectual debt—although unacknowledged by him in his 1968 paper-is to Hobbes's central thesis. In a later article, Hardin argued that to avoid ruin in an overpopulated world, 'people must be responsive to a coercive force outside their individual psyches, a 'Leviathan', to use Hobbes's term': G Hardin, 'Political Requirements for Preserving our Common Heritage' in HP Bokaw (ed), Wildlife and America (Council on Environmental Quality, 1978) 310, 314.

54 JS Dryzek, The Politics of the Earth: Environmental Discourses (Oxford University Press, 1997) 28; see also JL Taulbee, 'Law, Organization and Environmental Concerns' in DW Orr and MS Soroos (eds), The Global Predicament: Ecological Perspectives on World Order (University of North Carolina Press, 1979) 249; HM Enzensberger, 'A Critique of Political Ecology' (1974) 84 New Left Review 3-31.

55 See, for example, RD Holsworth, 'Recycling Hobbes: The Limits to Political Ecology' (1979) 20 The Massachusetts Review 19-40; RW Hoffert, 'The Scarcity of Politics: Ophuls and Western Political Thought' (1986) 8 Environmental Ethics 5-32; discussion by KJ Walker, 'The Environmental Crisis: A Critique of Neo-Hobbesian Responses, (1988) 21 Polity 67-81 and JS Dryzek, 'Designs for Environmental Discourse: The Greening of the Administrative State?' in R Paehlke and D Torgerson (eds), Managing Leviathan: Environmental Politics and the Administrative State (Belhaven Press, 199o) 97. 
radical concept out of a philosophical vacuum. It is still to be viewed as a frontier legal principle but one that was shaped and influenced by ideas and norms percolating in the surrounding context from which it emerged.

\subsection{Development and Meaning}

There are numerous formulations of the precautionary principle in treaties, legislation and policy documents. As noted above, its formulation in the 1992 Rio Declaration is the most often cited notwithstanding that when deconstructed it has been criticized as being more reflective of the preventative principle rather than the precautionary principle. ${ }^{56}$ Other formulations have sought to lower the trigger for precautionary measures, place greater emphasis on the need to respond to the challenges of scientific uncertainty, or use positive action phraseology. Examples include the 1998 Wingspread Statement on the Precautionary Principle, ${ }^{57}$ the 2000 European Commission Communication on the Precautionary Principle, ${ }^{58}$ and the 2000 Cartagena Protocol on Biosafety. ${ }^{59}$ There has been considerable scholarly analysis of the 'chameleon-like'60 principle and its core meaning. ${ }^{61}$ Perennial concerns are

56 W Gullett, 'The Threshold Test of the Precautionary Principle in Australian Courts and Tribunals: Lessons for Judicial Review' in Fisher, Jones and von Schomberg (eds), above (n 9), 182, 185 .

57 'When an activity raises threats of harm to human health or the environment, precautionary measures should be taken even if some cause and effect relationships are not fully established scientifically'.

$5^{8}$ 'The precautionary principle applies where scientific evidence is insufficient, inconclusive or uncertain and preliminary scientific evaluation indicates that there are reasonable grounds for concern that the potentially dangerous effects on the environment, human, animal or plant health may be inconsistent with the high level of protection chosen by the EU'. See, for example, J Peel, Science and Risk Regulation in International Law (Cambridge University Press, 2010) 138.

592226 UNTS 208, Art 10(6) reads: 'Lack of scientific certainty due to insufficient relevant scientific information ... shall not prevent the Party of import, in order to avoid or minimize such potential adverse effects, from taking a decision, as appropriate, with regard to the import of the living modified organism in question'. This version of the principle prompted fierce debate. See, for example, H Miller and G Conko, 'The Protocol's Illusory Principle' (2000) 18 Nature Biotechnology 360; 'Correspondence' (2000) 18 Nature Biotechnology 697; H Miller and G Conko, 'Precaution Without Principle' (2001) 19 Nature Biotechnology 302-303.

6o C Tollefson and J Thornback, 'Litigating the Precautionary Principle in Domestic Court' (2008) 19 Journal of Environmental Law and Practice 33-58, 36.

61 For a recent and excellent comprehensive analysis, see E Persson, 'What Are the Core Ideas behind the Precautionary Principle?' (2016) 557-558 Science of the Total Environment 134141. Numerous other surveys exist, for example, $S$ LaFranchi, 'Surveying the Precautionary Principle's Ongoing Global Development: The Evolution of an Emergent Environmental 
that formulations of the principle do not provide clear guidance on when and how to apply precaution ${ }^{62}$ leading to the most strident criticism that application of the principle is arbitrary. ${ }^{63}$ Without some threshold then critics of the principle would be correct to assert that it is a 'marvellous piece of rhetoric' that allows the prohibition of any activity that could cause harm. ${ }^{64}$ Some minimum content and legal meaning must be ascribed to the principle's threshold or trigger so that it cannot be a complete shield for environmental managers. ${ }^{65}$ There must be some reason to assume the occurrence of an unacceptable environmental outcome to justify precautionary action. Yet it is patently not precautionary to wait until such time as there is cogent evidence of 'serious' or 'irreversible' environmental damage. Actions to address such risks are preventative rather than precautionary.

Many formal definitions of the precautionary principle stipulate required levels of knowledge of potential environmental harm to justify precautionary action and, together with the abundant literature and policy documents, also point to some straightforward and tangible instructions about how to be precautionary. These include: 66

Management Tool' (2005) 32 Boston College Environmental Affairs Legal Review 679-720; E Soule, 'Assessing the Precautionary Principle' (2000) 14 Public Affairs Quarterly 309-328; P Sandin, 'Dimensions of the Precautionary Principle' (1999) 5 Human and Ecological Risk Assessment 889-907.

62 Gullett (2006), above ( $\mathrm{n}_{5}$ 6), 185-186; Persson, above (n 61), 135.

63 See, for example, GE Marchant and KL Mossman, Arbitrary and Capricious: The Precautionary Principle in the European Union (AEI Press, 2004); N McNelis, 'EU Communications on the Precautionary Principle' (2000) 3 Journal of International Economic Law 545-551. See also, for example, Gray's concerns about the rejection of statistical predictions of environmental outcomes in favour of mere 'suspicion of effects' as sufficient for the application of precautionary measures, thus forsaking objectivity: Gray, above (n 7$), 174$.

64 A Wildavsky, But Is It True? A Citizen's Guide to Environmental Health and Safety Issues (Harvard University Press, 1995) 428, 445.

65 Gullett (2006), above (n 56), 199; E Fisher, "The Precautionary Principle as a Legal Standard for Public Decision-making: The Role of Judicial and Merits Review in Ensuring Reasoned Deliberation' in R Harding and E Fisher (eds), Perpectives on the Precautionary Principle (Federation Press, 1999) 83, 9o.

66 For further discussion on components of the precautionary principle and its underlying rationale, see, for example, J Tickner, C Raffensperger, and N Myers, The Precautionary Principle in Action: A Handbook (Science and Environmental Health Network, 1999); D VanderZwaag, 'The Precautionary Principle in Environmental Law and Policy: Elusive Rhetoric and First Embraces' (1999) 8 Journal of Environmental Law and Practice 355-375; T O'Riordan and A Jordan, 'The Precautionary Principle in Contemporary Environmental Politics' (1995) 4 Environmental Values 191-212, 195-198; Gullett (1997), above (n 9), 57-6o. 
- using the best available scientific information in decision-making;

- explicitly recognizing the level and type of uncertainty that may exist concerning the environmental consequences of human activities (for example, predictions of stock resiliency to a certain amount of fishing effort); and

- allowing the level of regulations pertaining to a human activity with environmental impacts to increase once pre-determined target reference points are exceeded.

The precautionary principle is concerned with decision-making processes in situations of uncertainty rather than determining particular outcomes. ${ }^{67}$ At its heart is the need for explicit awareness of the various forms of uncertainty 68 about environmental consequences that may attach to current or prospective human endeavours, enhancement of knowledge of such consequences, and proactive minimization of the likelihood of their occurrence. According to Freestone and Hey,

Once the precautionary principle is seen in 'non-absolutist' terms and not as a dogmatic absolute regulatory rule then ... its implementation and the consequences of its implementation pose problems at both a conceptual level and at a practical level. Conceptually a principle which

67 E Fisher, 'Is the Precautionary Principle Justiciable?' (2001) 13 Journal of Environmental Law 315-334, 319 .

68 The uncertainty which attaches to predictions of environmental outcomes is a combination of the difficulties associated with analysing complex systems and the nature of scientific inquiry itself. Uncertainty arises where baseline data are unavailable or incomplete due to time or resource constraints or where there are environmental agents which are incapable of being monitored or monitored over a sufficiently long period: Gullett (1997), above (n 9), 53; A Goudie, 'Environmental Uncertainty' (1993) 78 Geography 137-141, 137; $\mathrm{R}$ Costanza and L Cornwell, 'The $4 \mathrm{P}$ Approach to Dealing with Scientific Uncertainty' (1992) 3 Environment 12-42, 13. For a taxonomy of uncertainty, see VR Walker, 'The Siren Songs of Science: Toward a Taxonomy of Scientific Uncertainty for Decisionmakers' (1991) 23 Connecticut Law Review 567-626, 572; Wynne, above (n 10), 114; Tickner, Raffensperger and Myers, above (n 66), 12. M'Gonigle et al. neatly encapsulated the dilemma faced by environmental decision-makers seeking to respond to the problems created by uncertainty: '[I]ntrinsic variability in natural ecosystems, cumulative and synergistic effects, confounding factors, large inherent uncertainty, and the prevalence of low statistical power ... makes it difficult to establish clearly cause-effect relationships between certain substances or processes and environmental degradation': RM M'Gonigle, TL Jamieson, MK McAllister and RM Peterman, 'Taking Uncertainty Seriously: From Permissive Regulation to Preventative Design in Environmental Decision Making' (1994) 32 Osgoode Hall Law Journal 99-169, 111. 
purports to provide an agenda to react to uncertainty provides a number of problems for traditional legal thinking. ${ }^{69}$

The principle is not a hard and fast rule but rather seeks to ingrain flexibility and broader goal-setting in decision-making ${ }^{70}$ such as recommending buffers against catastrophe and enhancement of limited capacity. ${ }^{71}$ The principle aligns with the adaptive management approach, whereby margins for error can be adopted by acknowledging uncertainties and enabling the area affected by a proposed activity to be expanded as the extent of uncertainty is reduced. ${ }^{72}$ Steps include monitoring of impacts, further research to reduce uncertainties, periodic evaluation and establishing an efficient and effective compliance system. ${ }^{73} \mathrm{O}$ 'Riordan and Jordan identified the conceptual core of the principle as:

[T] he intuitively simple idea that decision makers should act in advance of scientific certainty to protect the environment (and with it the wellbeing interests of future generations) from incurring harm ... In essence, it requires that risk avoidance becomes an established decision norm where there is reasonable uncertainty regarding possible environmental damage or social deprivation arising out of a proposed course of action. ${ }^{74}$

The precautionary concept embodies two key aspirations for decisionmaking: there should be confidence about predictions of future environmental effects of activities before they are permitted; and regulators and managers should not wait for conclusive proof of environmental harm of existing activities before adopting remedial measures. It has been characterized as a legal principle 'in the Dworkinian sense' in so far as it influences decisions but does not necessarily determine them. ${ }^{75}$ One of the clearest common sense

69 D Freestone and E Hey, 'Implementing the Precautionary Principle: Challenges and Opportunities', in D Freestone and E Hey (eds), The Precautionary Principle and International Law: The Challenge of Implementation (Kluwer Law International, 1996) 249,25 .

$70 \quad$ Fisher, above (n 24), 16.

71 SR Dovers, TW Norton, and JW Handmer, 'Uncertainty, Ecology, Sustainability and Policy' (1996) 5 Biodiversity and Conservation $1143^{-1167,1160 . ~}$

72 BJ Preston, 'The Judicial Development of the Precautionary Principle' (2018) 35 Environmental and Planning Law Journal 123-141, 139.

73 Ibid citing Telstra Corp Ltd v Hornsby Shire Council (2006) 67 NSWLR 256, 276.

74 O'Riordan and Jordan, above (n 66), 194.

75 R Briese, 'Precaution and Cooperation in the World Trade Organization: An Environmental Perspective' (2002) 22 Australian Yearbook of International Law 113-162, 126. 
explanations of the precautionary principle provides conceptual clarity for how it assists in decision-making: the principle provides the 'philosophical authority to take decisions in the face of uncertainty. ${ }^{\prime}{ }^{7}$ While instinctively sound common sense expressions of the principle abound - it is difficult to deny it is always better to 'err on the side of caution' 77 - it is the exact wording of the principle in treaties, legislation and overarching policy documents, often with significant or subtle variations, that is critical to enable identification of its context-specific meaning and the bounds of lawful decision-making, and how institutional culture is shaped to embrace or spurn precautionary approaches.

\section{Implementation of the Precautionary Principle in Marine Environmental Management}

There are a myriad of potential areas of application of the precautionary principle in marine environmental management decision-making, ranging from exploitation of living and non-living marine resources (encompassing activities such as fishing, aquaculture development, and seabed material extraction) to management of land and vessel activities (including land and vesselsourced pollution, passage of vessels with hazardous cargo or through hazardous environments, and habitat protection). The principle can be used at either the domestic or international level, including regional regimes, involving different legal frameworks. There is arguably greater potential in domestic legal regimes for the principle to be adopted in a manner that is explicit and which

76 J Cameron, W Wade-Gery and J Abouchar, 'Precautionary Principle and Future Generations' in E Agius and S Busuttil (eds), Future Generations and International Law (Earthscan, 1998) 93; see also J Cameron, 'The Precautionary Principle: Core Meaning, Constitutional Framework and Procedures for Implementation' in Harding and Fisher (eds), above (n 65), 29, where the explanation was slightly expanded: the precautionary principle provides 'philosophical authority to take public policy decisions concerning environmental protection in the face of uncertainty'.

77 Gro Harlem Brundtland, former Prime Minister of Norway and chair of the World Commission on Environment and Development, famously encapsulated the principle thus: 'If we err in our decisions affecting the future of our children and our planet, let us err on the side of caution': J Cameron and J Abouchar, 'The Precautionary Principle: A Fundamental Principle of Law and Policy for the Protection of the Global Environment' (1991) 14 Boston College International and Comparative Law Review 1-27, 1. Surprisingly, this expression has found its way into legislation. Canada has arguably the most imprecise and elusive legislative definition of the precautionary approach: 'that is, erring on the side of caution': Oceans Act, sc 1996, c 31, s 30 (c) (Canada). 
mandates specified decision-making processes or outcomes than in international regimes where there generally is a need to balance competing viewpoints of States and imbue provisions with acceptable ambiguity. Domestic statutory decision-making functions generally can be prescribed with greater specificity than their multilateral treaty counterparts and the decision-making competence of statutory officers is often more clearly delineated. As such, the principle can be seen as functioning differently at the international level. Apart from situations where detailed articulation of the principle can be achieved, for example, in a regional treaty concerning a discrete decision-making process such as EIA, the principle is most likely to be expressed in international agreements as a high-level policy objective. Detailed implementation is largely left to individual States, determined in accordance with national policy and domestic legislative practice.

This section first overviews international and regional encapsulations of the precautionary principle in marine resource management and then examines its utilization in Australia's domestic fisheries regime to seek to identify trends and level of use. However, identifying and characterizing the employment of the precautionary principle is a challenging task. This is because of the various guises in which it can appear in legal and policy documents, its contested conceptualizations, and the potential for it to meld with other decision-making norms which blurs its emergence as a discrete obligation. Fisher opined that searching for a 'common understanding' of the precautionary principle can be seen as a 'fruitless activity' because of perceptions that it is too inexact to serve as a regulatory standard notwithstanding that there is ample evidence that judges, legislators and administrators have expressly employed the principle in decision-making. ${ }^{78}$

\subsection{International Marine Environmental Management}

The precautionary principle has been invoked frequently in marine environmental management, generating abundant scholarly analysis. This section reviews the adoption and use of the principle in the two sectors most responsible for its development as an international legal principle: marine pollution regulation and fisheries management. Nevertheless, it is clear that the principle is suitable for use in numerous other fields of marine resource management, and indeed much has been achieved to formalize its role in these fields, including management of high risk vessels ${ }^{79}$ and the regulation in areas

\footnotetext{
78 Fisher, above (n 24), 15 .

79 See, for example, B Sage-Fuller, The Precautionary Principle in Marine Environmental Law, with Special Reference to High Risk Vessels (Routledge, 2013).
} 
beyond national jurisdiction of deep seabed mining ${ }^{80}$ and the protection of biodiversity. ${ }^{81}$ The principle appears in numerous multilateral marine management treaties and has enjoyed slow but steady judicial support in the handful of international cases in which it has been litigated. Although the 1982 United Nations Law of the Sea Convention (LOSC) ${ }^{82}$ predates the appearance of the precautionary principle on the international stage and explains the absence of its express mention within the environmental protection provisions, there are components of the treaty which resonate with the principle, complemented by subsequent State practice which has provided solid support for it as either a specific consideration or as an overarching approach in marine resource management. As stated by Rayfuse, " $[t]$ he language of precaution, the precautionary principle and the precautionary approach have entered the lexicon of the law of the sea. ${ }^{83}$

\subsubsection{Marine Pollution Control}

It is unsurprising that the precautionary principle resonates with the task of addressing environmental harm caused by pollution, especially the oftenslow cumulative build-up of multiple point-source pollution in the marine

8o The precautionary approach is considered a direct obligation on States to ensure certain conduct on the part of sponsored contractors of deep seabed activities. The obligation is found within the duty of 'due diligence' and is linked with the obligation on States to adopt best environmental practices and to conduct environmental impact assessments: Responsibilities and Obligations of States Sponsoring Persons and Entities with Respect to Activities in the Area, Advisory Opinion, 1 February 2011, 2011 ITLOS Reports, p 10 at [125-135] 46. See also, International Seabed Authority, Regulations on Prospecting and Exploration for Polymetallic Nodules in the Area (2000); Regulations on Prospecting and Exploration for Polymetallic Sulphides in the Area (2010); JM Durden, LE Lallier, K Murphy et al., 'Environmental Impact Assessment Process for Deep-sea Mining in "The Area"' (2018) 87 Marine Policy 194-202; AL Jaeckel, The International Seabed Authority and the Precautionary Principle: Balancing Deep Seabed Mineral Mining and Marine Environmental Protection (Brill Nijhoff, 2017).

81 In the process of the United Nation's efforts to develop an international legally binding instrument on the conservation and sustainable use of marine biological diversity of areas beyond national jurisdiction, most States share the view that the precautionary approach could be included as a general guiding principle. See United Nations, Report of the Preparatory Committee established by General Assembly resolution 69/292:Development of an international legally binding instrument under the United Nations Convention on the Law of the Sea on the conservation and sustainable use of marine biological diversity of areas beyond national jurisdiction, UN doc A/AC.287/2017/PC.4/2, (31 July 2017).

82 Adopted 10 December 1982, in force 16 November 1994, 1833 UNTS 3.

83 R Rayfuse, 'Precaution and the Protection of Marine Biodiversity in Areas beyond National Jurisdiction' (2012) 27 International Journal of Marine and Coastal Law 773-781, 773; see also Marr, above (n 12). 
environment. Marine pollution - comprising lawful permitted discharges and accidental or deliberate discharges - directly engages core precepts of precaution: addressing uncertainty and seeking sound scientific bases for action. The principle is a philosophical shift for pollution regulators who traditionally relied on the assimilative capacity concept which assumes that ecosystems can tolerate a certain amount of pollution without detrimental changes to overall quality ${ }^{84}$ Although rarely is it disputed that the environment - and in particular the vast greatness of the marine environment - has some capacity to tolerate human activities and wastes, the assimilative capacity concept has limitations in protecting against environmental harm, in part because it assumes thresholds of environmental capacity can be determined..$^{85}$ The principle is attentive to the possibility of causation of irreversible environmental damage in such circumstances and supports taking action to avoid harm before it manifests. ${ }^{86}$

Following the precautionary principle's emergence internationally in the 198 os in the context of multilateral attempts to address marine pollution in the North Sea, there were attempts to craft more exacting legal requirements about how precaution was to be used in decision-making. The strongest - and arguably most problematic - formulation of the principle can be found in the 1989 decision of the Oslo Commission on the reduction and cessation of dumping of industrial wastes in the North Sea. The parties agreed that

the dumping of industrial wastes in the North Sea shall cease ... except for inert materials of natural origin, and except for those industrial wastes for which it can be shown to the Commission through the Prior Justification Procedure (PJP) both that there are no practical alternatives on land and that the materials cause no harm in the marine environment. ${ }^{87}$

The burden of proof is thus reversed (from freedom to dispose of wastes until such time that there is proven causation of harm) and it becomes necessary for the waste disposer to demonstrate that the disposal of wastes at sea will cause

84 Cameron and Abouchar, above ( $\mathrm{n}$ 77), 2. By definition, permitted discharges purportedly are made without risking unacceptable harm: ARD Stebbing, 'Environmental Capacity and the Precautionary Principle' (1992) 24 Marine Pollution Bulletin 287-295, 288.

85 See T Jackson and PJ Taylor, 'The Precautionary Principle and the Prevention of Marine Pollution' (1992) 7 Chemistry and Ecology 123-134, 124-126.

86 See further chapter 11, this volume (Nilüfer Oral).

87 Reproduced in Freestone (1991), above (n 27), 25. 
'no harm' before approval can be granted. ${ }^{88}$ Such strong formulations of the principle provoked criticism because of the almost impossible task of proving a negative proposition, that no harm will be caused. ${ }^{89}$ As Stebbing pointed out, 'only disproof is logically conclusive' because repudiating what is false is the only act scientists can perform with complete certainty. ${ }^{90}$ Insisting upon application of such formulations of the principle is quixotic because, taken to its logical conclusion, the principle entails the prohibition of all activities about which there exists uncertainty as to environmental effects - virtually every human activity. Even allowing for the 'balance of probabilities' burden of proof that is used in civil law (whereby the scientific evidence might suggest that on the balance of probabilities there will be 'no harm' caused by the disposal of a particular pollutant) and subjective dimensions of what is actionable environmental 'harm', a blanket rule only to allow an activity if it has been proven to cause 'no harm' would take use of the precautionary principle too far because of tortuous logic and interpretational subjectivity.

The Oslo Commission's early standard for the precautionary principle was soon ameliorated, yet the current version, now in the broader 1998 Convention for the Protection of the Marine Environment of the North-East Atlantic (OSPAR Convention), remains one of the most stringent versions of precautionary standard-setting in any multilateral environment treaty. It provides:

The Contracting Parties shall apply the precautionary principle, by virtue of which preventive measures are to be taken when there are reasonable grounds for concern that substances or energy introduced, directly or indirectly, into the marine environment may bring about hazards to human health, harm living resources and marine ecosystems, damage amenities or interfere with other legitimate uses of the sea, even when there is no conclusive evidence of a causal relationship between the inputs and the effects. ${ }^{91}$

88 Freestone argued that the prior justification principle is 'the most rigorous application' of the precautionary principle in that it 'places the burden of proof on the applicant to demonstrate that no harm will be caused to the marine environment': ibid.

$89 \quad$ Ibid 32 ; Gray, above ( $\mathrm{n} 7)$.

90 Stebbing, above (n 84), 292. According to Popper, for a statement genuinely to be scientific, it must be conclusive. Only statements which falsify (rather than verify) propositions can be conclusive. 'Proof' of harmlessness is a universal statement which is falsifiable: K Popper, The Logic of Scientific Discovery (Hutchinson, 1959, originally published in German, 1934). 
As explained by Wang, this formulation of the precautionary principle 'combines preventive and precautionary measures and lowers the level of scientific evidence required. If there is reason to presume that harm might be caused, the precautionary principle should be adopted.' ${ }^{92}$ It dispenses with the reference commonly found in other international documents that the trigger for precautionary action is threat of 'serious and irreversible' damage. This strong version of the precautionary principle, which creates 'a positive obligation for contracting parties to take immediate measures to protect the marine environment even where there is lack of full scientific evidence', has led to criticism of overregulation and practical difficulties to enforce the standard. ${ }^{93}$ Yet it has enabled precautionary decisions because of the positive obligation, supported by clear substantive measures such as applying best environmental practice and best available technology guidelines, ${ }^{94}$ and its adoption of a reverse listing approach whereby the dumping of waste and other listed matter in Annex II is prohibited. ${ }^{95}$ Implementation practice by OSPAR reveals that the precautionary principle is invoked or relied upon for many of its measures, including those aimed at protected habitats, including marine protected areas (MPAs) in areas beyond national jurisdiction. ${ }^{96}$ The precautionary principle is prominent in numerous other international instruments designed to guard against marine pollution, including as a binding legal principle under the 1992 Helsinki Convention on the Protection of the Marine Environment of the Baltic Sea Area, and is found in other agreements of relevance to protecting the marine environment including the 2001 Stockholm Convention on Persistent Organic Pollutants, ${ }^{97}$ and international agreements to address land-based sources of marine pollution. ${ }^{98}$

92 See R Wang, 'The Precautionary Principle in Maritime Affairs' (2011) 10 WMU Journal of Maritime Affairs 143-165, 145; see also, Marr, above (n 12), 124.

93 Wang, above (n 92), 148.

94 L de La Fayette, 'The OSPAR Convention Comes into Force: Continuity and Progress' (1999) 14(2) International Journal of Marine and Coastal Law 247-297, 250-255.

95 See Marr, above (n 12), 122; 1996 London Protocol to the 1972 Convention on the Prevention of Pollution by Dumping of Wastes which 'requires a precautionary reverse listing approach where only wastes listed on a "safe list" may be disposed of at sea and only after government regulators require a waste assessment': VanderZwaag (2002), above (n 1), 168.

96 See ospar Commission website http://www.ospar.org; K Houghton, 'Identifying New Pathways for Ocean Governance: The Role of Legal Principles in Areas beyond National Jurisdiction' (2014) 49 Marine Policy 118-126, 124.

97 Marr, above (n 12), 55; 1992 Helsinki Convention, 2099 UNTS 195; 2001 Stockholm Convention, 2256 UNTS 119.

98 For discussion on the Helsinki Convention, among other measures, see, e.g., D VanderZwaag, 'Land-based Marine Pollution and the Arctic: Polarities between Principles 


\subsubsection{Fisheries}

It is unsurprising that the precautionary principle has been a popular inclusion in fisheries management measures, spanning international, regional and national laws and policies, in light of the uncertainties that bedevil fisheries management. As a principle that States that scientific uncertainty should not be a reason to avoid taking protective action, it promises a means of addressing the problems at the root of past fishery collapses. The principle is apposite for fisheries management because uncertainties abound in the marine environment, especially in terms of limited knowledge of ecological processes and the level of impact fishing activities have on target species, associated and dependent species and marine habitat. ${ }^{99}$ Further, there is an understandable lack of precision in modelling the complex marine environment. Assessment models typically grossly simplify fisheries systems, and many of the data used in the assessment of fisheries resources and fisheries management measures contain errors. ${ }^{100}$ It is, for example, a difficult if not a futile task to determine accurately the maximum sustainable yield (MSY) of a targeted species because of the need, among other requirements, to identify the abundance of the stock when fish do not lend themselves to observation. In addition to knowing stock size, to determine the MSY of a species it is also necessary to know previous harvest levels and the life cycle, fecundity and recruitment patterns of the species. This information may be unavailable or unreliable. ${ }^{101}$ It is also common for assessments to be made of the catch that can be taken of a particular species without knowledge of relative population strengths of predator species, and species upon which they prey, and other variables such as impacts of climate change and variations in salinity. For example, in a rapidly developing fishery, it is difficult to determine the appropriate bounds for exploitation when the impacts on stocks are unlikely to be known until the limits of the fishery have been reached, at which time it may be too late and remedial management measures will need to be put in place. The ability to regulate has been severely limited by

and Practice' in D Vidas (ed), Protecting the Polar Marine Environment: Law and Policy for Pollution Prevention (Cambridge University Press, 2000) 175, 189.

99 W Gullett, Fisheries Law in Australia (LexisNexis, 2008) 119; see also F González-Laxe, 'The Precautionary Principle in Fisheries Management' (2005) 29(6) Marine Policy 495-505.

100 JA Wilson, JM Acheson, M Metcalfe and P Kleban, 'Chaos, Complexity and Community Management of Fisheries' (1994) 18 Marine Policy 291-305.

101 SB Kaye, International Fisheries Management (Kluwer, 2001) 163; see also GL Kesteven, 'MSY Revisited: A Realistic Approach to Fisheries Management and Administration' (1997) 21 Marine Policy 73-82, 73-76; DM Dzidzornu, 'Four Principles in Marine Environmental Protection: A Comparative Analysis' (1998) 29 Ocean Development and International Law 91-123, 99-100. 
a lack of knowledge even though past experiences attest to the risks of overfishing. ${ }^{102}$ The precautionary principle is ideally suited to guiding decision-making in such circumstances. There are many ways to operationalize the principle in fisheries management due to the numerous management measures available. These range from, for example, establishing cautious quotas, prohibiting open access fisheries and destructive fishing gear and techniques, requiring environmental assessments before approving new fisheries, allowing fish to spawn at least once, to setting aside protected areas and promoting consideration of fisheries in integrated coastal area management. ${ }^{103}$

The precautionary principle can also lend itself to perplexing application in fisheries management. Arguably the most significant aspect of the principle is its call to increase the knowledge base on which decisions are made. As such, a decision to increase the quota of a targeted species may be consistent with the precautionary principle if it is made with support of a detailed and convincing stock assessment which examined areas of uncertainty. This is because the decision-making framework was robust and competently addressed the concerns about uncertainty which are the focus of the principle. Further, the principle could not be invoked to justify restrictions on fishing effort, such as a fishing closure or area prohibition, in the absence of evidence pointing to the harmfulness of existing practices. It also should be borne in mind that where such evidence exists, a range of precautionary measures may be adopted. Rather than restricting fishing effort, the first precautionary measure may simply be to increase monitoring. The next level of precautionary intervention, where some evidence can support it, may be to trial an area restriction within the fishery. Yet such a precautionary measure can be revoked if fish stocks rebound.

The development and application of the precautionary principle owes much to its widespread adoption and implementation in the international fisheries management context. ${ }^{104}$ The most detailed articulation of the 'precautionary

102 M McGarvin, 'Fisheries: Taking Stock' in P Harremoës, D Gee, M MacGarvin et al., Late Lessons from Early Warnings: The Precautionary Principle 1896-200o (European Environment Agency, 2001) 17.

103 VanderZwaag (2002), above (n 1), 168; see also, W Edeson, D Freestone and E Gudmundsdottir, Legislating for Sustainable Fisheries: A Guide to Implementing the 1993 FAO Compliance Agreement and 1995 UN Fish Stocks Agreement (World Bank, 2001).

104 For example, Australia relied on the precautionary principle in the international arena in the Southern Bluefin Tuna cases. See S Marr, 'The Southern Bluefin Tuna Cases: The Precautionary Approach and Conservation and Management of Fish Resources' (2000) 11 European Journal of International Law 815-831. See also Kaye, above (n 101); Freestone (1999), above (n 21), 135; GJ Hewison, 'The Precautionary Approach to Fisheries Management: An Environmental Perspective' (1996) 11 International Journal of Marine 
approach' is in the 1995 UN Fish Stocks Agreement. ${ }^{105}$ The Agreement provides that conservation and management measures for straddling fish stocks and highly migratory fish stocks for the high seas and areas under national jurisdiction shall be compatible. ${ }^{106}$ Article 6(1) provides that 'States shall apply the precautionary approach widely to conservation, management and exploitation of straddling fish stocks and highly migratory fish stocks in order to protect the living marine resources and preserve the marine environment'. Further instructions are given, including that States 'shall be more cautious when information is uncertain, unreliable or inadequate', and - consistent with Principle 15 of the Rio Declaration - States shall not use the absence of adequate scientific information 'as a reason for postponing or failing to take conservation and management measures.'107 In implementing the precautionary approach, States are obliged to adopt various fisheries management measures. These include improving decision-making for fishery resource conservation and management 'by obtaining and sharing the best scientific information available and implementing improved techniques for dealing with risk and uncertainty', taking into account uncertainties, including those relating to the size and productivity of stocks, and developing data collection and research programs to assess the impact of fishing on non-target and associated or dependent species and

and Coastal Law 301-332; JM MacDonald, 'Appreciating the Precautionary Principle as an Ethical Evolution in Ocean Management' (1995) 26 Ocean Development and International Law 255-286, 270. Article 7.5 FAO Code of Conduct for Responsible Fisheries urges States 'to apply a precautionary approach widely'. The Code requires, among other measures, that a precautionary approach be adopted to conserve aquatic resources and to protect the aquatic environment (Article 6.5). FAo Code of Conduct for Responsible Fisheries, adopted 31 October 1995, FAO Doc 95/20/Rev/1 (1998).

105 Above (n 34); see also, e.g., European Commission Communication to the Council and the European Parliament on the Application of the Precautionary Principle and Multiannual Arrangements in the Setting of Total Allowable Catches (2000). See D Freestone, 'Implementing Precaution Cautiously: The Precautionary Approach in the Straddling and Highly Migratory Fish Stocks Agreement' in E Hey (ed), Developments in International Fisheries Law (Kluwer, 1999) 287, 305-309; Freestone and Makuch, above (n 34); VanderZwaag (2002), above (n 1); J Ellis, 'The Straddling Stocks Agreement and the Precautionary Principle as Interpretive Device and Rule of Law' (2001) 32 Ocean Development and International Law 289-311.

106 UN Fish Stocks Agreement, above (n 34), Art 7(2). See AG Oude Elferink, The Impact of Article 7(2) of the Fish Stocks Agreement on the Formulation of Conservation and Management Measures for Straddling and Highly Migratory Fish Stocks, FAO Legal Papers Online \#4 (1999), http://www.fao.org/3/a-bbo37e.pdf; G Rose, 'Marine Biodiversity Protection through Fisheries Management: International Legal Developments' (1999) 8(3) RECIEL 284-29o.

107 UN Fish Stocks Agreement, above (n 34), Art 6(2). 
their environment. ${ }^{108} \mathrm{~A}$ key aspect is the obligation to determine, on the basis of the best scientific information available, stock-specific reference points and the action to be taken if they are exceeded. ${ }^{109}$ Predetermined fisheries management measures to restore stocks must be taken 'without delay' in the event that reference points are exceeded. ${ }^{110}$ Monitoring is required of non-target or associated or dependent species, ${ }^{111}$ and cautious conservation and management measures are required for new or exploratory fisheries. ${ }^{112}$

The precautionary principle also appears in many regional fisheries agreements, normally expressly ${ }^{113}$ but sometimes implicitly, ${ }^{114}$ and is used as a basis for decision-making. ${ }^{115}$ Assessments of regional fisheries management organization (RFMO) practice for tuna species has found that the precautionary approach is applied irrespective of the absence of its explicit reference in some constituent instruments, ${ }^{116}$ especially in regard to the use of the best science available for decision-making and the protection of biodiversity. Its elaboration and operationalization by tuna RFMOs has supported the principle's elevation as customary international law, complemented by the incorporation of

108 Ibid Art 6(3).

109 Ibid Art 6(3)(b); Annex II, 'Guidelines for the application of precautionary reference points in conservation and management of straddling fish stocks and highly migratory fish stocks'.

110 Ibid Art 6(4).

111 Ibid Art 6(5).

112 Ibid Art 6(6).

113 See, for example, 200o Convention on the Conservation and Management of Highly Migratory Fish Stocks in the Western and Central Pacific Ocean, 2275 UNTS 43, Art 6; 2012 Convention on the Determination of the Minimal Conditions for Access and Exploitation of Marine Resources, https:// www.itlos.org/fileadmin/itlos/documents/cases/case no.21/ Convention_CMA_ENG.pdf, Art 2(2), read with Arts 61 and 62; Request for an Advisory Opinion Submitted by the Sub-Regional Fisheries Commission (SRFC), Advisory Opinion, 2 April 2015, ITLOS Reports 2015, p 4.

114 See, for example, 1980 Convention on the Conservation of Antarctic Marine Living Resources, 1329 UnTS 47, Art II(3).

115 See, for example, P de Bruyn, H Murua and M Aranda, 'The Precautionary Approach to Fisheries Management: How This is Taken into Account by Tuna Regional Fisheries Management Organisations (RFMOs)' (2013) 38 Marine Policy 397-406; GR Galland, AEM Nickson, R Hopkins and SK Miller, 'On the Importance of Clarity in Scientific Advice for Fisheries Management' (2018) 87 Marine Policy 250-254; DG Miller, 'Fisheries Management and Precautionary Approach: Progress and Performance' (2013) 5 Australian Journal of Maritime and Ocean Affairs 8o-96.

116 P Manoa, The Contribution of Tuna Regional Fisheries Management Organisations to International Law, PhD thesis, University of Wollongong, Australia (2016) 129. 
the precautionary approach in national fisheries legislation of many member States as evidence of State practice and opinio juris. ${ }^{117}$

\subsection{Australian Fisheries Law}

The precautionary principle was embedded early in Australia's management approach to fisheries. Its adoption was linked to the concomitant entrenchment within law and policy of the 'sustainable development' concept. In Australia, the sustainability concept is generally expressed as 'ecologically sustainable development' (ESD). ESD has been accepted and promoted as the key objective in natural resource planning and development since the early1990s. ${ }^{118}$ ESD is at the core of the 1992 Intergovernmental Agreement on the Environment (IGAE). The IGAE was signed by the Commonwealth, States and Territories and the Australian Local Government Association and expressly adopted the precautionary principle, modelled closely on the Rio Declaration formulation. ${ }^{119}$ Thus, while it is laudable that Australia was one of the first countries to embrace the precautionary principle in legislation, a shortcoming is that the Rio-esque version of the precautionary principle adopted is vague and does not set a high precautionary duty.

The IGAE set up a framework for improved environmental management throughout Australia and supported the development of a largely uniform legislative approach to the adoption of the precautionary principle throughout Australia's states and territories as well as the federal system. ESD is found in all major pieces of Australian environmental legislation and policy documents, and thus sustainability - inclusive of the precautionary principle - is the overarching objective of fisheries management in Australia. All pieces of Australian fisheries legislation either refer to $\mathrm{ESD}^{120}$ or a variant of it, such as 'sustainability'. ${ }^{21}$ The precautionary principle is either expressly mentioned in Australian fisheries legislation or implicitly included by virtue of the legislative commitment to the sustainable development concept.

It stands to reason that a stronger precautionary mandate exists in jurisdictions where the fisheries legislation expressly mentions the principle. However,

\footnotetext{
117 Ibid 341.

118 Commonwealth of Australia, National Strategy for Ecologically Sustainable Development (Australian Government Publishing Service, 1992).

119 Gullett (2008), above (n 99), 112-113.

120 Fisheries Management Act 1991 (Cth), s 3A; Fisheries Management Act 1994 (NSW), s 3(2) (c); Fisheries Act 1994 (Vic), s 3(a); Fisheries Act 1994 (Qld), s 3(1); Fisheries Act 1988 (NT), s $2 \mathrm{~A}(\mathrm{a})$; Fisheries Act 2000 (АСТ), s $3(\mathrm{a}),(\mathrm{b})$.

121 Living Marine Resources Management Act 1995 (Tas), s 7(1); Fish Resources Management Act 1994 (WA), s 3(2)(b).
} 
express mention of the principle and its particular formulation are not the only matters relevant to how it is embraced in administrative decision-making. Another crucial aspect is how the obligation to be precautionary is expressed. A unique feature of the incorporation of the principle in the Australia's federal fisheries legislation, the Fisheries Management Act 1991 (Cth) (FM Act), is that the objective must be 'pursued.'.122 This is a higher standard than what exists in every other piece of federal or state legislation which includes the principle (which typically is 'must consider' or 'take into account'), thus giving the federal fisheries agency, the Australian Fisheries Management Authority (AFMA), the strongest precautionary mandate of any Australian government agency. Nevertheless, in all cases where fisheries legislation provides that the principle must be considered or pursued, it must be done so in accordance with the advancement of other prescribed objectives. In some cases, these may include consideration of social impacts and in all cases they include consideration of economic objectives, thus ensuring a difficult task for fisheries managers to act consistently with a number of objectives which may be in tension with each other. The legislative duty placed on AFMA is that it must pursue, among other objectives including implementing cost-effective management and maximizing the net economic returns to the Australian community from the management of Australian fisheries, the objective of ensuring that the exploitation of fisheries resources and the carrying on of any related activities are conducted in a manner consistent with the principles of ecologically sustainable development (which include the exercise of the precautionary principle), in particular the need to have regard to the impact of fishing activities on non-target species and the long term sustainability of the marine environment. ${ }^{123}$

Industry concern that the precautionary principle can unfairly harm commercial fishers, and thus is unmeritorious as a basis for fisheries management, was memorably articulated by John Olsen in his provocative editorial 'Precautionary principle needs sensible definition' in the February 2003 issue

122 The Fisheries Management Act 1991 (Cth) was amended in 1997 explicitly to require the Australian Fisheries Management Authority (AFMA) to pursue the precautionary principle in the carrying out of its functions. The s $3(1)(\mathrm{b})$ objective read, in part, that AFMA must pursue the objective of ensuring fishing activities are conducted 'in a manner consistent with the principles of ecologically sustainable development and the exercise of the precautionary principle'. In 2006, the manner in which the precautionary principle was expressed was revised slightly: Fisheries Legislation Amendment (Cooperative Fisheries Arrangements and Other Matters) Act 2006 (Cth), ss 2, 5. The rephrasing of the objective possibly de-emphasizes the duty on AFMA to ensure the exercise of the precautionary principle. See Gullett (2008), above (n 99), 120.

123 Fisheries Management Act 1991 (Cth), s 3(1)(b). 
of The Queensland Fisherman. ${ }^{124}$ Olsen criticized the principle as being a 'pie in the sky' concept which nonetheless is a 'sledgehammer head of power without an actual measure of substance for controlling its use', thus rendering uncertain the 'prognosis for economic stability and industry certainty'. The 'indiscriminate' use of the principle, 'used so flagrantly' in the fishing industry, like a 'runaway train', led Olsen to pose the question 'is such a principle just a hammer designed as an uncontrolled tool of curtailment for the commercial fishing industry?'

These types of concerns, stemming from the invocation of the precautionary principle by fisheries agencies to justify new fisheries restrictions, led to a series of legal challenges in Australia in the early-20oos to fisheries management decisions on the basis that they were too precautionary. ${ }^{125}$ These merits and judicial review appeals stand in contrast to early precautionary principle litigation in Australia in which aggrieved individuals objected to development consents, submitting that a statutory authority or government department failed to properly fulfil its legislative duty to take the principle into account when arriving at a decision. ${ }^{126}$ Put simply, the argument in these cases was that the administrative decision being reviewed, or the process leading to the decision, was not precautionary enough. They were all unsuccessful largely because the obligation to consider the precautionary principle in arriving at a decision can be met in a perfunctory way. Similarly, all of the challenges to fisheries decisions on the basis that they were impermissibly precautionary also failed. This is likely due to the general deference merits tribunals give to departmental interpretation of legislation and the amorphous nature of the legislative incorporation of the precautionary principle. ${ }^{127}$ Nevertheless, courts and tribunals have struggled to construe fisheries and environmental legislation in a manner that supports a department's decision. The key stumbling block in Australian cases has been the threshold question. For example,

124 J Olsen, 'Precautionary Principle Needs Sensible Definition' (2003) 21(2) The Queensland Fisherman 2. For a response, seeW Gullett and P McShane, 'In Defence of the Precautionary Principle' (2003) 21(4) The Queensland Fisherman 25.

125 For criticism that Australian fisheries management is insufficiently precautionary, see J Nevill, Overfishing Under Regulation: The Application of the Precautionary Principle and the Ecosystem Approach in Australian Fisheries Management (Verlag, 2010).

126 Gullett (2006), above (n 56), 189.

127 This approach is not unique to Australia. For a recent example from the Cook Islands, see Framhein and Anor v Attorney-General and Ors, High Court (civil division) plt no. 18/2017, Cook Islands (Potter J, judgment 15 December 2017). Cf, the rejection of the deference approach by courts to administrative agencies by the High Court of Australia in Corporation of the City of Enfield v Development Assessment Commission (2000) 199 CLR 135. See also P Cloutier de Repentigny, 'Precaution, Sub-Delegation and Aquaculture Regulation: Morton v Canada (Fisheries and Oceans)' (2015) 28 Journal of Environmental Law and Practice 125-153. 
in AJKA V AFMA [2003] FCA 248, the Federal Court of Australia did not disturb the finding of the Administrative Appeals Tribunal (AAT) that the uncertain state of skipjack tuna stocks means there is a 'risk of serious environmental damage'. Thus, the AAT considered that scientific evidence did not support a conclusion that there was a threat of serious or irreversible environmental damage yet it equated the level of uncertainty that existed with this high evidentiary standard. This supported a precautionary decision but the reasoning is suspect because a high level of knowledge about extent of environmental harm and its likelihood of occurrence is needed to conclude there is a risk of serious or irreversible environmental harm.

The precautionary principle came to the fore at the highest level in the fisheries management context in 2012 when it was the centrepiece of a cabinetlevel decision to prevent the world's second largest fishing vessel from fishing in Australian waters. A rushed temporary amendment to the Environment Protection and Biodiversity Conservation Act 1999 (Cth) (Е PBC Act) was made to enable the Environment Minister to impose a precautionary fishing ban on the 'super trawler' FV Abel Tasman. ${ }^{128}$ On 30 August 2012, the 142-metre-long Lithuanian-registered and Dutch-owned refrigerated factory fishing vessel had arrived in South Australia in anticipation of its Australian operator, Seafish Tasmania, gaining approval to use it to fish for its share of the quota set for the Small Pelagic Fishery, which stretches from Western Australia to southern Queensland. On 3 September 2012, Seafish Tasmania nominated the vessel for use in connection with its fishing concession totalling 17,800 tonnes of fishing quota. This was against the backdrop of AFMA issuing reassuring statements that it had 'found no evidence that larger boats pose a higher risk to either commercial species or broader marine ecosystem when total catches are limited and the limits are enforced' and its 'robust management of fisheries will ensure that any fishing is sustainable, ${ }^{\prime 29}$ counterbalanced by extremely vocal opposition to the vessel (especially from recreational fishers and environmentalists) amid fear of it causing localized depletion of target stock and impacting threatened species.

128 The vessel has previously and subsequently been registered under other names, and in different countries. See W Gullett, 'Legislative Development of the Precautionary Principle: The ЕРвC Amendment (Declared Commercial Fishing Activities) Act 2012 and Forthcoming Changes to the Fisheries Management Act 1991' (2012) 28(1) Australian Environment Review 405-410.

129 AFMA, Fishing Regulator Re-affirms Management is Watertight, Media Release, 26 July 2012. 
On 4 September 2012, the Environment Minister announced that the vessel would need to adhere to stringent operating conditions designed to avoid fatal interactions with dolphins, seals and sea birds, including the use of an underwater camera and an automatic suspension of fishing in the event of a specified number of dolphin or seal deaths. On 11 September 2012, following Cabinet and Labor Party Caucus approval, a Bill was introduced into parliament designed to amend the ЕРвC Act to enable the Environment Minister to go further than simply setting operating conditions for fishing vessels by authorizing the prohibition of certain fishing activities. The Environment Protection and Biodiversity Conservation Amendment (Declared Commercial Fishing Activities) Act 2012 (Cth) (EPBCA (DCFA) Act) enabled virtually any new commercial fishing activity to be prohibited while an assessment is conducted by a specially appointed expert panel. An interim declaration could be made where the Environment and Fisheries Ministers agree that there is 'uncertainty about the environmental impacts' of the activity. Such an order was made for the vessel on the day after the Act entered into force, and subsequently withstood a judicial review challenge. ${ }^{130}$

The expression 'uncertainty about the environmental impacts' was intended to provide maximum power to make precautionary decisions, yet it would have been prone to abuse if it had been adopted in the principal legislation as the threshold to trigger application of the precautionary principle because it would have provided the fisheries agency with virtually unlimited discretion. It would have given credence to the perception by some commercial fishers noted above that that the precautionary principle is a 'runaway train' used to curtail commercial fishing activity because uncertainty is ever-present in the marine environment, and thus it could be feared that any level or type of uncertainty could be identified to be the legislatively-authorized basis for restricting or prohibiting fishing activities. It is difficult to imagine any type of fishing activity that does not involve some level of environmental uncertainty whether it is related to the abundance or distribution of target species, correct recording of bycatch interactions, seabed environment disturbance, or any other manner of environmental interaction. This conundrum is an illustration of the challenge of how best to articulate the precautionary principle in legislation.

The decision of the Environment Minister to utilize the Е РвС Act to prevent the FV Abel Tasman from fishing in Australian waters provided the perfect timing for the announcement of a review of fisheries legislation because of the

130 Seafish Tasmania Pelagic Pty Ltd v Burke, Minister for Sustainability, Water, Population and Communities (No 2) [2014] FCA 117. 
apparent inconsistency between the direction of decision-making under the EPBC Act and the FM Act. The review focused squarely on the precautionary principle. This is evident from the terms of reference, which stated:

[T] he ability of the Minister for Fisheries to enact the precautionary principle is limited due to gaps in scientific knowledge, limits on the scope of the precautionary principle considerations, limits on how quotas are determined, limits on the considerations that apply in quota management, cross-agency considerations such as the relationship with the Department of Sustainability, Environment, Water, Population and Communities, and interactions with other legislation such as the [EPBC Act].

It is therefore considered that the advice from the lead agency, the Australian Fisheries Management Authority to the Minister for Fisheries is limited in delivering on the expectations sought from the precautionary principle objective of the [FM Act]. As a consequence, the powers of the Minister to make decisions based on the precautionary principle are therefore equally limited in their scope, and the community is exposed to a less than sustainable model of fisheries management.

In light of new challenges within Australian fisheries management, the full objectives of the precautionary principle are now sought.

The review of the [fisheries legislation] will ... Recommend any necessary changes to the Acts that affirm the powers of a Minister to take advice, and make decisions, with the full scope of the precautionary principle. ${ }^{131}$

Despite such an explicit endorsement of the precautionary approach and strong indication of the need for an even more explicit legislative precautionary mandate for fisheries management, the legislation has not been revised. The review report did not recommend specific change to the way in which the principle is expressed in the fisheries legislation. With respect to its central task of examining the application of the precautionary principle to fisheries management, the Review stated ' $[\mathrm{t}$ ] his can be a vexed area, although in the Review's opinion, while it is an area where judgements may differ, there is often more heat than light when it comes to different points of view'.132 It went further and summarized the primary ground for differing views between

\footnotetext{
131 See D Borthwick, Review of Commonwealth Fisheries: Legislation, Policy and Management (Australian Government, 2012) 148.

132 Ibid 137.
} 
fisheries and environmental groups on the application of the precautionary principle to fisheries:

- Those who believe they should be allowed to keep fishing at existing levels until there is irrefutable evidence that the decline in stocks and impacts on the marine environment have led to an unsustainable fishery. Those holding this view are prone to claim that the data is inconclusive; the fishery naturally is prone to variable catch rates and the like. While issues of this kind are being analysed, fishing often continues, exacerbating the stock decline.

- Those who believe, especially as fish stocks are a public resource, that it is incumbent on fishers (and governments that regulate them) to provide irrefutable evidence that proposed catch levels are sustainable. Sometimes the threshold evidence requirements demanded are so large that the costs of collection would be problematic, whether funded by fishers or by government. Until the uncertainties are resolved, fishing should be limited.

Such polar views are seldom helpful in practice. ${ }^{133}$

AFMA - constantly criticized and often litigated for its reliance on the precautionary principle - made a submission that called for clearer formal guidance on how precaution is to be implemented, stating 'Fisheries management and the ensuing public debate would benefit from clarification of the application of the precautionary principle under both the fisheries Acts and the EPBC Act through a national policy and/or legislative amendments.'. ${ }^{34}$ The approach recommended by the Review was for more detailed articulation of how various principles should be applied in more specific contexts, such as approaches to harvest strategy policy for target species, bycatch and discards, ecosystem effects and management plans for individual fisheries. ${ }^{135}$

While the enactment of the EPBCA (DCFA) Act may be seen as an aberration, designed to achieve a decision arrived at in politically-charged circumstances, it is not the case that the FM Act lacks a strong precautionary mandate. Rather, a strange set of circumstances prevented the FM Act being used to prohibit the Fv Abel Tasman at the relevant time. This is explained by the nature of the legislative fishing rights in Australia. A fishing company requires both a quota and authorization to use a vessel. In this case, the assessment of the quota available in the fishery and its allocation to the fishing company was made well ahead of the time when the fishing company sought authorization

\begin{tabular}{ll}
\hline 133 & Ibid 138. \\
134 & Ibid 55. \\
135 & Ibid 139.
\end{tabular}


to use the FV Abel Tasman to fish for its quota. By this stage, because the vessel met standards under the FM Act, there was no ability under the Act to prevent the company from using the vessel. However, the issue of whether it is appropriate to use such a large vessel could have been incorporated much earlier in the management plan for the fishery under the authority of the precautionary principle as expressed in the Act, yet there was no perceived need to consider the use of a large super trawler at that time. The circumstances of the application for the FV Abel Tasman to be licensed to fish in Australia provide insight into the way in which fisheries management can be a complex and conflicting interplay between the operation of fisheries and environmental legislation, the latter which might not be constrained, or to the same extent, by needing to promote economic viability of commercial activities.

\section{$4 \quad$ Conclusion}

Precaution has become entrenched as a bedrock principle in numerous legal and policy frameworks for management of marine resources and ecosystems at international, regional and domestic levels. The precautionary principle has improved marine management decision-making by facilitating explicit consideration of uncertainty about environmental consequences of human activities across numerous sectors that utilize or impact marine environments. It has enabled the making of specific decisions that implement precautionary responses to risks of environmental harm or resource depletion, notably in setting fisheries management measures and prohibiting or restricting the discharge of marine pollutants, but extending to many other fields. As further brief examples, precautionary thinking has underpinned the setting of aquaculture license conditions, ${ }^{136}$ design of MPA s, ${ }^{137}$ ship routing measures, ${ }^{138}$

136 For example, the application of adaptive management for salmon farms in coastal marine areas was held to be consistent with proper implementation of the precautionary approach by the Supreme Court of New Zealand in Sustain Our Sounds Incv The New Zealand King Salmon Co Ltd [2014] 1 NZLR 673, 716 [158]. See Preston, above (n 72) and Cloutier de Repentigny, above (n 127).

137 For example, Canada has proposed amendments to the Oceans Act 1996 (above $\mathrm{n} 77$ ) to require application of the precautionary principle when designating a new marine protected area: Bill C-55 (First Reading, House of Commons, 15 June 2017), Clause 35.2.

138 See, for example, the authority of the Marine Environment Protection Committee of the International Maritime Organization (IMO) to adopt non-binding resolutions in which it can designate a marine area to be a 'Particularly Sensitive Sea Area' (PSSA). A PSSA is defined as 'an area that needs special protection through action by Iмо because of its significance for recognized ecological, socio-economic, or scientific attributes where such attributes may be vulnerable to damage by international shipping activities'. 
compulsory pilotage regulations, ${ }^{139}$ management of ballast water, ${ }^{140}$ development of options to minimize anchoring impacts on seafloor biota, ${ }^{141}$ and the conduct of Can replace with EIAs. for activities that might cause significant harm to the marine environment. ${ }^{142}$ In some cases, formal marine resource management decision-making frameworks expressly adopt

Imo, Resolution A.982(24): Revised guidelines for the identification and designation of Particularly Sensitive Sea Areas, adopted 1 December 2005. PSSAs must be linked to existing or proposed specific protective measures that would protect a proposed PSSA from an identified risk of environmental damage from international shipping. 'Associated Protective Measures' can be used to regulate international shipping, such as specifying routeing requirements, discharge restrictions, no-anchoring areas, vessel reporting and installation of vessel traffic services. PSSAs can cover areas outside national jurisdiction on the basis that the Imo Resolution does not prescribe any jurisdictional requirement for the designation of a PSSA. However, thus far none of the PSSAs cover high seas. See D Freestone and V Harris, 'Particularly Sensitive Sea Areas beyond National Jurisdiction: Time to Chart a New Course?' in MH Nordquist, JN Moore and R Long (eds), International Marine Economy: Law and Policy (Brill Nijhoff, 2017) 322.

139 See, for example, Australia's pioneering extension of the use of pilots outside ports in waters which are challenging for navigation, experience high rates of ship movements and encompass areas that are highly valued for environmental features. In 1991, Australia introduced compulsory pilotage in sections of the Great Barrier Reef and subsequently extended this to other areas. See W Gullett, 'Regulation of Navigation of Foreign Vessels in Australia' in S Lee, K Zou and T McDorman (eds), Foreign Vessel Navigation in the AsiaPacific (Brill/Martinus Nijhoff, 2018) 199.

140 See International Convention for the Control and Management of Ships' Ballast Water and Sediments, adopted 13 February 2004, in force 8 September 2017, Iмо Doc вWм/ CONF/36 (16 February 2004).

141 See AR Davis, A Broad, W Gullett et al., 'Anchors Away? The Impacts of Anchor Scour by Ocean-Going Vessels and Potential Response Options' (2016) 73 Marine Policy 1-7.

142 For example, the operation of the 1991 Espoo Convention enables precautionary approaches. The preamble mentions the need to develop 'anticipatory policies', and there is also a requirement for assessment reports to include a statement indicating predictive methods and assumptions used, as well as data gaps and 'uncertainties encountered'. Convention on Environmental Impact Assessment in a Transboundary Context (Espoo Convention), 1989 UNTS 309, Appendix II, parts (f) and (g). See W Gullett, 'Environmental Decision-making in a Transboundary Context: Principles and Challenges for the DenmarkSweden Øresund Fixed Link' (200o) 2 Journal of Environmental Assessment Policy and Management 503-533. Further, in Responsibilities and Obligations of States Sponsoring Persons and Entities with Respect to Activities in the Area (n 80), the Seabed Disputes Chamber of ITLOS, in its first decision and in the first advisory opinion requested of it, delivered an unanimous judgment concerning activities for the recovery of resources in the Area, such as polymetallic nodules and polymetallic sulphides. The decision is influential because it elaborated and set high standards for 'due diligence'. Within this duty it confirmed the legal obligation on States to apply the precautionary approach (para 131) and adopt best environmental practices, and for States sponsoring activities in the Area to conduct EIA (para 145). 
the precautionary principle and enable its application to be tested by courts; in other cases precaution is more of an overarching philosophical approach for managing human activities in marine environments. The precautionary principle has largely been accepted as the operating context for marine environmental management notwithstanding numerous different articulations of the precautionary principle in treaties, legislation and policy documents.

The precise contours of the precautionary principle for environmental management decision-making are destined to remain elusive. It continues to be imperfectly distinguished from the principle of prevention of environmental harm and its meaning appears to be frustratingly irreducible beyond hortatory language such as having confidence about the environmental impacts of new activities before allowing them, or not waiting for conclusive proof of harm before adopting remedial measures for existing activities. Nevertheless, in some sectors the principle has crystallized into a more robust decision-making framework. The UN Fish Stocks Agreement stands out as a detailed and articulate expression of how a series of precautionary approaches can be applied for the development of management measures for fisheries. This road map for precaution has influenced the development of numerous fisheries management plans beyond those concerning only straddling and highly migratory stocks. Yet more fleshing-out of the principle in legislation and treaties is needed to ensure robust, transparent and consistent decision-making. The high objective that precaution must be 'pursued' in the FM Act permeates the culture in Australia's fisheries authority to the point that it routinely faces merits review challenges to its decisions for being too precautionary, but support for strong precautionary decision-making can also be provided by other formulations. For example, although 'precaution' is not mentioned in the Fisheries Act 1996 $(\mathrm{NZ})$, the Act contains greater detail than the FM Act about precautionary elements of decision-making which are mandatory considerations for persons exercising or performing functions, duties, or powers under the Act. ${ }^{143}$ These

143 The 'information principles' set out in s 10 are 'decisions should be based on the best available information', 'decision makers should consider any uncertainty in the information available in any case', 'decision makers should be cautious when information is uncertain, unreliable, or inadequate', and 'the absence of, or any uncertainty in, any information should not be used as a reason for postponing or failing to take any measure to achieve the purpose of [the] Act'. However, almost perversely, the precautionary instructions in $\mathrm{s}$ 1o had the effect of precluding three important precautionary fisheries decisions by the New Zealand Fisheries Minister: Northern Inshore Fisheries Company Ltd $v$ Minister of Fisheries (High Court, 4 March 2002); Squid Fishery Management v Minister of Fisheries (High Court, 11 April 2003); Squid Fishery Management v Minister of Fisheries (Court of Appeal, 13 July 2004). See also New Zealand Federation of Commercial Fishermen Inc $v$ 
approaches reveal how the precautionary principle can be articulated as a specific obligation for the process of decision-making under resource management legislation but achieve greater effect: operating to influence and shape broad institutional thinking to ensure precaution informs the entirety of management approaches, helping to identify solutions to the problems resulting from ever-present environmental uncertainty.

Differences of opinion will remain about the application of the precautionary principle. It is inevitable that there will be decisions that are opposed for being too precautionary or not precautionary enough. This is because the application of the principle normally involves accepting a burden such as an economic cost or known risk of environmental harm to guard against an uncertain - and possibly negligible - environmental outcome. The principle can justify quick responsive action when there is reason to assume - but not yet conclusive proof - that environmental harm may occur. Although the principle no longer appears to be perceived as radical, individual manifestations of precautionary decisions will always carry the risk that the consequences for those who have been adversely affected by a decision will claim the precautionary response is excessive or without foundation. Yet few now would argue that precautionary considerations are irrelevant to environmental management decision-making. Case law in New South Wales bears out this observation. For example, in Port Stephens Pearls Pty Ltd $v$ Minister for Infrastructure and Planning [2005] NSWLEC 426, concerning a developer's appeal against a Ministerial decision to reject development consent for a pearl farm, despite the precautionary principle not being mentioned in the applicable legislation, Talbot J considered it was required to be considered when determining development applications because the legislation specified that account must be taken of the public interest which brings with it the obligation to have regard to the principles of ecologically sustainable development including the precautionary principle. ${ }^{\prime} 14$

Writing nearly 25 years ago, the present author commented:

Minister of Fisheries (High Court, 23 February 2010). See Gullett, above (n 56), 196-198; NR Wheen, "How the Law Lets Down the "Down-Under Dolphin": Fishing-Related Mortality of Marine Animals and the Law in New Zealand' (2012) 24Journal of Environmental Law 477-497.

144 Port Stephens Pearls Pty Ltd v Minister for Infrastructure and Planning [2005] NSWLEC 426, [54]; W Gullett, 'Contesting the Merits of Aquaculture Development: Port Stephens Pearls Pty Ltd v Minister for Infrastructure and Planning [2005] NSWLEC 426' (2006) 11 Australasian Journal of Natural Resources Law and Policy 109-117, 113-114; see also Leatch $v$ Director-General of National Parks \& Wildlife and Shoalhaven City Council (1993) 81 LGERA 270. 
The principle is in a crucial transitional phase. While its merits as an environmental philosophy are virtually unquestioned, the debate has shifted to the more difficult aspect of its potential to amount to more than a nebulous 'guiding principle' for environmental protection. ... [Attention must shift] to developing specific operating criteria or 'rules' which must ensure the application of some minimum content and not allow precaution to be diminished. Otherwise the principle faces the prospect of being reduced merely to an unachievable aspiration for environmental management. ${ }^{145}$

It remains the author's contention that sound precautionary decision-making can best be achieved by developing coherent and systematic implementation guidance in law and policy documents. It is in the operational context in different sectors where frequent formal decisions are required such as in licensing for resource extraction or approval for development activities that fleshingout of precautionary approaches and considerations can be most helpful. Such approaches - achieved with most success in fisheries management but also seen in other fields such as aquaculture regulation ${ }^{146}$ - aids in transparency and consistency of decision-making and are more likely to reduce potential for disputation.

In 2002 VanderZwaag concluded:

Even if precaution is embraced in law, lack of political will and limited human and financial resources may hinder implementation. Precautionary standard-setting at the international level is thwarted by state sovereignty concerns and the lack of effective global governance, such as an empowered world environment organization. ${ }^{147}$

These challenges will inevitably remain. Yet precautionary thinking is now more pervasive within many of the institutions and agencies entrusted to manage marine environments and activities. Nevertheless, commitment to the principle in some jurisdictions is lacklustre, undermined by poor articulation of it in regulatory documents. For example, 'full integration' of the

\footnotetext{
145 Gullett (1997), above (n 9), 64-65.

146 See above (n 136).

147 VanderZwaag (2002), above (n 1 ), 176.
} 
precautionary principle is yet to be achieved in the 2013 European Parliament and Council Directive on safety of offshore oil and gas operations, ${ }^{148}$ and it is 'almost absent' in Bangladesh's management framework for fisheries. ${ }^{149}$ Further, the United Kingdom has not explicitly incorporated the principle in domestic legislation; instead relying on its adoption in European Union instruments. The Brexit decision thus renders vulnerable the legal basis for the precautionary principle in the United Kingdom.

The future for the precautionary principle in marine environmental management has been secured, as evidenced by its inclusion in numerous international, regional and domestic legal and policy frameworks. It has come of age as the logically unimpeachable philosophical approach for the management of human interactions with the marine environment. Yet its implementation has been muted when considering the hopes pinned on it by its impassioned advocates in the 199os. It remains in the key law and policy documents but its further development has been limited, especially in sectors other than fisheries management. There is reluctance to prescribe the principle with greater specificity in rules and regulations, ${ }^{150}$ and regulators are averse to applying it dramatically. Yet it can also be observed that its application is now far less contentious in some sectors, almost smooth sailing. There is reasoned deliberation of precautionary options and there is awareness that the precautionary principle cannot be used to 'prop up' decisions which are unsupported by tenable evidence of risk of harm. ${ }^{151}$

148 L Schiano di Pepe, 'Environmental Law Principles in the European Union Legislation Governing Offshore Oil and Gas Operations' in K Zou (ed), Sustainable Development and the Law of the Sea (Brill/Nijhoff, 2017) 101, 112.

149 A Al Arif, 'The Legal Status of Precautionary Principle in International Fisheries Law and its Application in the Marine Fisheries Regime of Bangladesh' (2018) 3 Asia-Pacific Journal of Ocean Law and Policy 95-14, 95.

150 This is seen, for example, in the lack of further specificity in the E PвC Act 1999 (Cth), and foregone opportunities to revise the articulation of the precautionary principle in the FM Act 1991.

151 See Aldekerk P/L $v$ City of Port Adelaide Enfield and Environment Protection Authority [2000] SAERDC 47, 69-71, concerning an appeal against the refusal to grant development consent for the construction within a funeral home of a furnace for the cremation of human remains. The South Australian Environment Resources and Development Court had reservations as to whether this was a 'proper case for the application of the precautionary principle' because the scientific opinions expressed were that the emissions would not constitute an environmental threat. The Court approved the development application after making the following observation: 'In our view, there is insufficient scientific uncertainty ... to render this a case in which the precautionary principle might properly be used ... The precautionary principle should only be applied ... in those cases where there is genuine uncertainty or ignorance on relevant scientific matters and there 
The precautionary principle has lived up to the immense expectations placed on it in so far as it has become a decision-making norm in numerous marine environmental protection regimes, supported by inclusion in law and routinely operationalized by national and international resource management and environment agencies. This has meant that the tide has turned in the way the principle is perceived: it has shed its aura as a radical paradigm shift in environmental management. Yet its frontier dimensions as a legal concept are destined to remain because it will always operate at the margins of knowledge about environmental processes and tolerance to ever new and inventive human activities. Further, challenges remain for effective systematic integration and use of the precautionary principle. In 1999 Freestone cautioned that ineffective implementation of precautionary environmental regimes 'may be worse than worthless if they give the impression that all is well when the opposite is in fact true.'152 There is danger in regimes merely paying lip service to the precautionary principle without it serving as a basis for repeatable, consistent, reasoned, evidence-based decision-making.

After more than a quarter of a century of international practice, it is clear that more work is needed to fulfil the potential of the precautionary principle to support the sustainable management of marine activities. Some regimes either have poor or absent formal commitment to the principle or do not enable reasoned consideration and examination of precautionary measures. It remains the task for regulators to examine approaches to decision-making within their purview to continue to build a culture of taking uncertainty - in all its guises - seriously and demonstrably. Ideally management regimes should be able to identify whether the precautionary principle is being considered and be able to reflect iteratively upon substantive precautionary decisions. It is important to recognize differences in legal and administrative culture across jurisdictions and sectors, yet some challenges are faced in the same manner wherever they occur: a new activity is proposed in the marine environment about which considerable uncertainty exists as to its potential impact on environmental values, or there is reason to believe that an existing activity might be the cause of unacceptable environmental harm. These threats need to be dealt with wherever they are, and the precautionary principle is available to guide the identification and implementation of solutions.

is a risk of substantial impairment to the environment. It cannot be used to prop up a decision that is unsupported by tenable evidence'.

152 Freestone (1999), above (n 25). 